\title{
大規模テキスト知識ベースに基づく自動質問応答 一ダイアログナビー
}

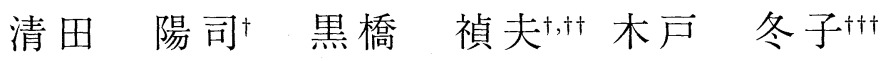

本論文では，大規模テキスト知識ベースに基づく対話的自動質問応答システム「ダイ アログナビ」について述べる．本システムは，2002 年 4 月からWWW 上で一般公開 し，パーソナルコンピュータの利用者を対象としてサービスを行っている。実世界で 用いられる質問応答システムにおいては，ユーザ質問の不明確さや曖昧性が大きな問 題となる。本システムは,「エラーが発生した」のような漠然とした質問について，対 話的に聞き返しを行うことによってユーザが求める答えにナビゲートする．聞き返し の方法としては，頻繁になされる漠然とした質問に対する聞き返しの手順を記述した 対話カードを用いる手法と，自動的に聞き返しの選択肢を編集して提示する手法を組 み合わせて用いている。また，適切なテキストを正確に検索するために，ユーザ質問 のタイプ，同義表現辞書や，日本語の文の係り受け関係などを利用している.

キーワード：対話システム，情報検索，質問応答，テキスト知識ベース

\section{Dialog Navigator :}

\section{A Question Answering System based on Large Text Knowledge Base}

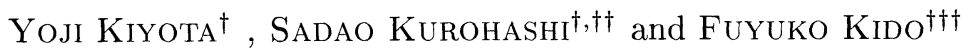

\begin{abstract}
This paper describes a dialog based QA system, Dialog Navigator, which can answer questions based on large text knowledge base. This system is targeted at users of personal computers. We released the system on the WWW in April 2002. In real world QA systems, vagueness of questions is a big problem. Our system can navigate users to the desired answers using the following methods: asking users back with dialog cards, and description extraction of each retrieved text. Another feature of the system is that it retrieves relevant texts precisely, using question types, synonymous expression dictionary, and modifier-head relations in Japanese sentences.
\end{abstract}

KeyWords: Dialogue System, Information Retrieval, Question Answering, Text Knowledge Base

\section{1 はじめに}

何かを調べたいとき，一番よい方法はよく知っている人 (その分野の専門家) に直接聞くこ とである，多くの場合，自分の調べたいこととその答えの間には，具体性のズレ，表現のズレ，

†東京大学大学院情報理工学系研究科, Graduate School of Information Science and Technology, The University of Tokyo

†† 科学技術振興事業団 さきがけ研究 21 , PRESTO, JST

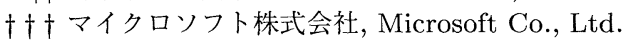


背景の認識の不足などがあるが，専門家は質問者との対話を通してそのようなギャップをうめ てくれるのである。

現在，WWW などに大規模な電子化テキスト集合が存在するようになり，潜在的にはどの ような質問に対してもどこかに答えがあるという状況が生まれつつある．しかし，今のところ WWW を調べても専門家に聞くような便利さはない. その最大の原因は，上記のようなギャッ プを埋めてくれる対話的な能力が計算機にないためである，例えば，ユーザがWWWのサー チエンジンに漠然とした検索語を入力すると多くのテキストがヒットしてしまい, ユーザは多 大な労力を費して適切なテキストを探さなければならない.

このような問題は，ドメインを限定し，ユーザが比較的明確な目的を持って検索を行う場合 でも同様である，我々は予備調査として，マイクロソフトが提供している自然言語テキスト検 索システム「話し言葉検索」1の検索ログを分析した。その結果, 全体の約 3 割の質問はその意 図が不明確であることがわかった。このような曖昧な質問に対しては多くのテキストがマッチ してしまうので，ユーザが検索結果に満足しているとはいいがたい。この問題を解決するため には,「曖昧な質問への聞き返し」を行うことが必要となる.

すでに実現されている情報検索システムには, 大きく分けてテキスト検索システムと質問応 答システムの 2 つのタイプがある。前者は質問キーワードに対して適合するテキスト(のリス ト)を返し，後者は質問文に対してその答えを直接返す。しかし，曖昧な質問を行ったユーザを 具体的なテキストまたは答えに導く必要性は両者に共通する，以下では,「曖昧な質問への聞き 返し」に焦点をあてて, 過去の研究を俯瞰する (表 1$)$.

テキスト検索システムにおいて，質問とテキストの具体性のギャップを埋めるために聞き返 しを行う方法としては，以下の手法が提案されてきた.

・テキストによる聞き返し

検索結果から適合テキストをユーザに判定させ，それを検索式の修正に反映させる手 法は, SMART システムなどで実験が行われている (Rocchio 1971) ${ }^{2}$. Google ${ }^{3}$ な゙の WWW サーチエンジンでは, 検索結果からテキストを 1 個選んで, その関連テキストを 表示させることができるが，この方法もユーザによる適合テキストの判定とみなすこと ができる。

・関連キーワードによる聞き返し

検索結果から，ユーザが入力したキーワードに関連するキーワードを抽出し，選択肢 として提示するシステムとしては, RCAAU (西村, 河野, 長谷川 1996), DualNAVI

\section{1 http://www.microsoft.com/japan/enable/nlsearch/}

2 このようにユーザが適合テキストを選ぶ方法は,「適合性フィードバック」とよばれている.しかし，ユーザに聞き返し を行って何らかの情報をえること全体が，広い意味での適合性フィードバックであるので，ここではその用語は用いて いない.

3 http://www.google.com/ 
表 1 情報検索の種々のタイプ

\begin{tabular}{|c|c|c|c|c|}
\hline 手法 / システム & ユーザ質問 & 出力 & 聞き返しの媒体 & 規模 \\
\hline 一一般的なテキスト検索システム & $\begin{array}{c}\text { キーワードの } \\
\text { リスト }\end{array}$ & $\begin{array}{l}\text { テキストの } \\
\text { リスト }\end{array}$ & $\bar{x}$ & $\overline{0}$ \\
\hline $\begin{array}{l}\text { テキストによる聞き返し } \\
\text { (SMART, WWW サーチエンジン) }\end{array}$ & $\begin{array}{c}\text { キーワードの } \\
\text { リスト }\end{array}$ & $\begin{array}{l}\text { テキストの } \\
\text { リスト }\end{array}$ & テキスト & O \\
\hline $\begin{array}{l}\text { 関連キーワードによる聞き返し } \\
\text { (RCAUU, DualNAVI, Excite) }\end{array}$ & $\begin{array}{c}\text { キーワードの } \\
\text { リスト }\end{array}$ & $\begin{array}{l}\text { テキストの } \\
\text { リスト }\end{array}$ & キーワード & 0 \\
\hline $\begin{array}{l}\text { テキストと関連キーワードによる } \\
\text { 聞き返し(THOMAS) }\end{array}$ & $\begin{array}{c}\text { キーワードの } \\
\text { リスト }\end{array}$ & テキスト & $\begin{array}{l}\text { テキストと } \\
\text { キーワード }\end{array}$ & $\Delta$ \\
\hline $\begin{array}{l}\text { クラスタリング } \\
\text { (Scatter/Gather, WebSOM) }\end{array}$ & $\begin{array}{c}\text { キーワードの } \\
\text { リスト }\end{array}$ & $\begin{array}{l}\text { テキストの } \\
\text { リスト }\end{array}$ & $\begin{array}{c}\text { クラスタ } \\
\text { (キーワード or } \\
\text { テキストで表現) }\end{array}$ & 0 \\
\hline $\begin{array}{l}\text { 人工言語による知識体系の利用 } \\
\text { (UC) }\end{array}$ & 自然言語 & $\begin{array}{l}\text { 自然言語 } \\
\text { (答え) }\end{array}$ & 自然言語 & $\bar{x}$ \\
\hline $\begin{array}{l}\text { FAQ テキストの利用 } \\
\text { (FAQ Finder) }\end{array}$ & 自然言語 & $\begin{array}{l}\text { 自然言語 } \\
\text { (答え) }\end{array}$ & $x$ & $\Delta$ \\
\hline $\begin{array}{l}\text { ドメイン独立テキストの利用 } \\
\text { (TREC QA / NTCIR QAC) }\end{array}$ & 自然言語 & $\begin{array}{l}\text { 自然言語 } \\
\text { (答え) }\end{array}$ & $\times$ & O \\
\hline 京都大学ヘルプシステム & 自然言語 & $\begin{array}{c}\text { 自然言語 } \\
\text { (答え) }\end{array}$ & 自然言語 & $\Delta$ \\
\hline "ダイアログナビ & 自然言語 & $\begin{array}{c}\text { 自然言語 } \\
\text { (状況説明文) }\end{array}$ & 自然言語 & O \\
\hline
\end{tabular}

(Takano, Niwa, Nishioka, Iwayama, Hisamitsu, Imaichi, and Sakurai 2000), Excite ${ }^{4}$ どがある。

・ テキストと関連キーワードを組み合わせた聞き返し

THOMAS (Oddy 1977) は，ユーザの情報要求を,「イメージ」とよばれるキーワード集 合として保持し，テキスト 1 個と関連キーワードを併せて提示してそれらの適合性をユー ザに判定させるプロセスを繰り返すことで,「イメージ」を徐々に具体化させようとする システムである。ただし，1970年代に提案されたシステムであり，小規模なテキスト集 合にしか適用できない。

・ クラスタリング

検索されたテキストをクラスタリングし，クラスタを選択肢として提示するシステムと しては, Scatter/Gather (Hearst and Pedersen 1996)，WEBSOM (Lagus 2000) などが ある。これらのシステムでは，各クラス夕は，それに属するテキストのリストや，代表 的なキーワードのリストとして表現されている.

これらのシステムの聞き返しの媒体は，いずれもキーワードまたはテキストのレベルであ る。しかし，キーワードは抽象化されすぎており表現力がとぼしく，逆にテキストは具体的す ぎるため, 聞き返しの媒体としては必ずしも適切ではない.

一方，質問応答システムとしては，1980 年代に UC (Wilensky, Arens, and Chin 1984) など 
のシステムが研究された。これらのシステムは，ユーザの意図が曖昧な場合に自然言語による 聞き返しを行う能力を備えていたが，そのためには人工言語で記述された，システムに特化し た知識ベースが必要であった。しかし, 十分な能力をもつ人工言語の設計の困難さ, 知識ベー ス作成のコストなどの問題から，このような方法には明らかにスケーラビリティがない.

1990 年代になって, 電子化された大量の自然言語テキストが利用可能になったことから, 自然言語テキストを知識ベースとして用いる質問応答システムの研究が盛んになってきたイイ ンターネットのニュースグループの FAQ ファイルを利用するシステムとしては, FAQ Finder (Hammond, Burke, Martin, and Lytinen 1995) がある.また最近は，構造化されていないドメ イン独立のテキスト (新聞記事や WWW テキスト) を用いた質問応答システムの研究が, TREC QA Track (NIST and DARPA 2001) や NTCIR QAC (Fukumoto, Kato, and Masui 2002) にお いて盛んに行われている (Harabagiu, Moldovan, Pasca, Mihalcea, Surdeanu, Bunescu, Gîirju, Rus, and Morărescu 2001; Ferret, Grau, Plantet, Illouz, Jacquemin, Masson, and Lecuyer 2001; Murata, Utiyama, and Isahara 2002; Kawahara, Kaji, and Kurohashi 2002). しかし, これらのシステムはユーザの質問が具体的であることを前提にして，1回の質問に対して答え を 1 回返すだけであり，曖昧な質問に対して聞き返しを行う能力は備えていない.

京都大学総合情報メディアセンターのヘルプシステム (Kurohashi and Higasa 2000) は, 自 然言語で記述された知識ベースとユーザ質問の柔軟なマッチングに基づいて，曖昧な質問に対 して自然言語による聞き返しを行うことができるシステムである。しかしそこでは，記述の粒 度をそろえ，表現に若干の制限を加えた知識ベースをシステム用に構築しており，「曖昧な質問 への聞き返し」のプロトタイプシステムという位置づけが適当である.

これに対して，本論文では，既存の大規模なテキスト知識ベースをもとにして，自然言語に よる「曖昧な質問への聞き返し」を行い，ユーザを適切なテキストに導くための方法を提案す る。具体的には, パーソナルコンピュータのWindows 環境の利用者を対象とした自動質問応答 システム「ダイアログナビ」を構築した (図 1). 本システムの主な特徵は以下の通りである.

- 大規模テキスト知識ベースの利用

マイクロソフトがすでに保有している膨大なテキスト知識ベースをそのままの形で利用 する。

\section{- 正確なテキスト検索}

ユーザの質問に適合するテキストを正確に検索する，そのために，質問タイプの同定，同 義表現辞書による表現のずれの吸収，係り受け関係への重みづけなどを行っている.

・ ユーザのナビゲート

ユーザが曖昧な質問をしたとき，対話的に聞き返しを行うことによってユーザを具体的 な答えにナビゲートする，聞き返しの方法としては，対話カードと状況説明文の抽出の 2 つの方法を組み合わせて用いる。どちらの方法が用いられても，システムは具体的な 


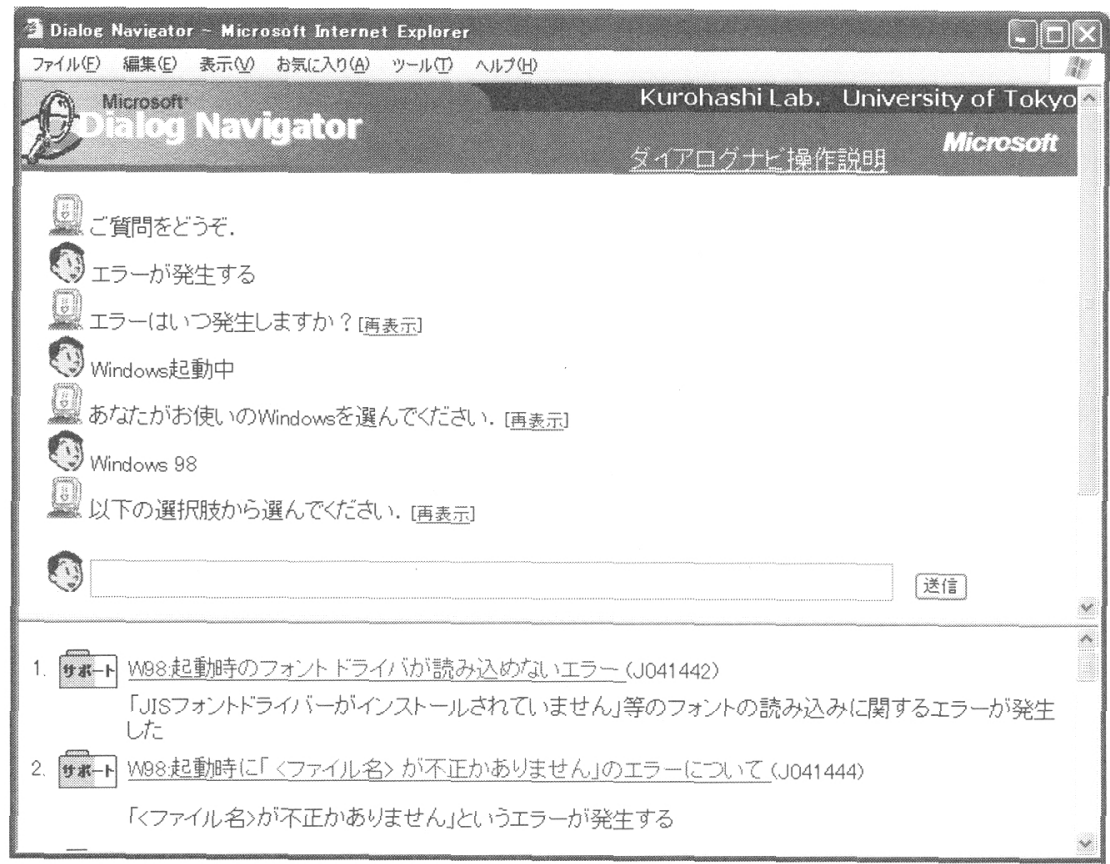

図 1 ダイアログナビのユーザインタフェース

フレーズを聞き返しの選択肢として提示する。

図 10例では,「エラーが発生する」という漠然とした質問に対して 2 回の聞き返しを行って ユーザの質問を対話的に明確化させた後，知識ベースを検索してその結果を提示している。そ の際, ユーザの質問をより具体化させるような部分を検索されたテキストから抽出して提示し ている。

本論文では，このような対話的質問応答を可能とするためのシステムを提案する。まず 2 節 において，システムの構成を示す。つづいて，3節では正確なテキストの検索を行うための手 法を，4節ではユーザのナビゲートを実現するための手法を，具体的に提案する。さらに5節に おいて, 提案手法を実装したシステム「ダイアログナビ」を公開運用して得られた対話データ ベースの分析結果を，提案手法の評価として示す。最後に6節で本論文のまとめを述べる. 
表 2 ダイアログナビで用いるテキスト知識ベース

\begin{tabular}{c|ccl}
\hline 知識ベース & 件数 & 文字数 & \multicolumn{1}{c}{ マッチング対象 } \\
\hline 用語集 & 4,707 & 700,000 & 見出し (1文) \\
ヘルプ集 & 11,306 & $6,000,000$ & タイトル (1 文) \\
サポート技術情報 & 23,323 & $22,000,000$ & 文書全体 (複数文) \\
\hline
\end{tabular}

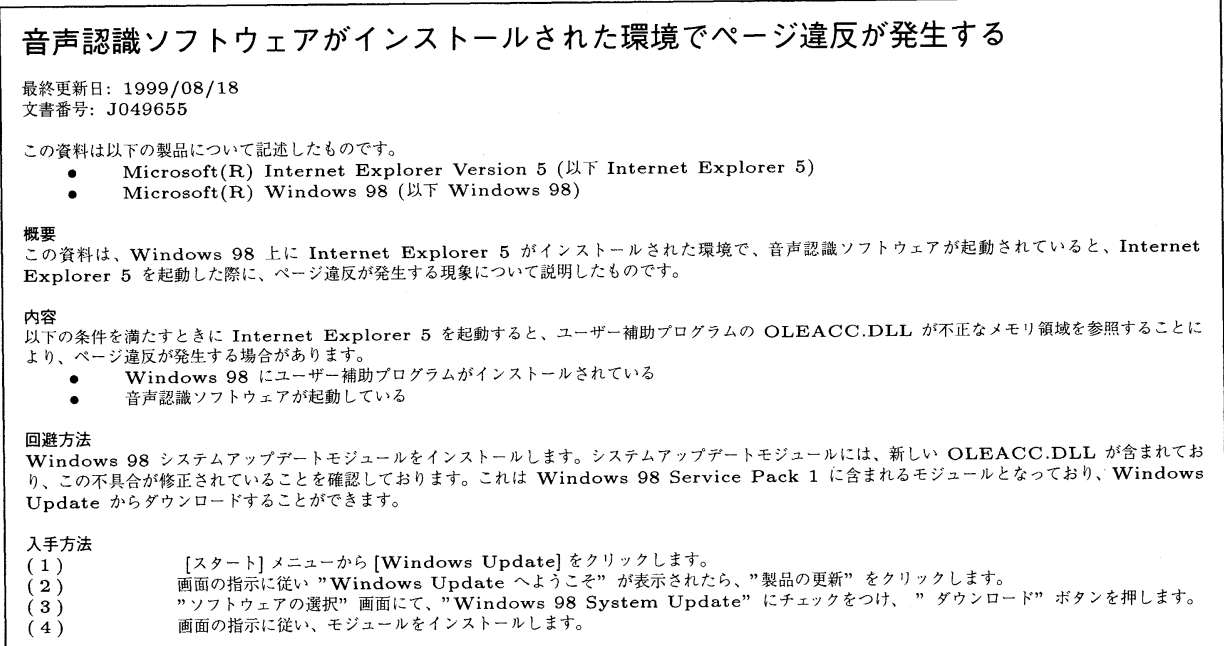

図 2 マイクロソフト・サポート技術情報の例

\section{2 ダイアログナビの構成}

ダイアログナビにおいて使用するリソースを以下に示す.

- 知識ベース

マイクロソフトがすでに一般に公開しているテキスト知識ベースをそのまま用いる。そ の種類と規模を表 2 に示す。また，知識ベースのうちサポート技術情報に含まれるテキ ストの例を図 2 に示す.

- 同義表現辞書 (3.2.1項, 困 3$)$ ユーザ質問文と知識ベースの間の表現のずれを吸収するために，同義語や同義フレーズ をグループ化した辞書を用いる．現在，ダイアログナビの同義表現辞書には，919グルー プの同義表現が存在し，3512 語・217フレーズが登録されている.

- 上位・下位語辞書 $(3.2 .2$ 項, 図 4)

上位・下位の関係にある語 (「ブラウザ」と「Internet Explorer」など) を関係づけた辞 書を用いる。現在, 200 語が登録されている. 


\section{[発生する]} [読む]

発生する，起きる，おきる，起こる，おこる [メール]

読む，よむ，読める，よめる，読み込む，上みこむ，読み込める，よみこめる メール, メイル，電子メール，電子メイル， Mail，E-Mail [メールを読む $]$

メールを読む，メールを受信する，メールを見る，メールを受ける，メッセージを 受信する,メッセージを受ける

[パソコンを起動する]

パソコンを起動する, Windows を起動する，電源を入れる，電源をオンする，ブー ト寸る，パソコンを立ち上げる，スイッチを入れる

図 3 同義表現辞書の例

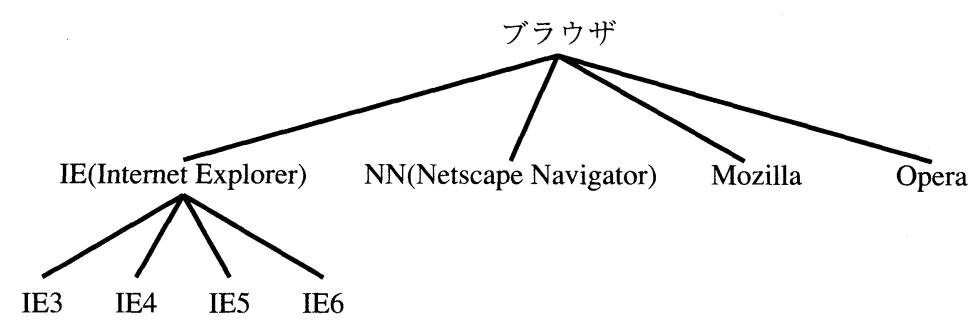

図 4 上位. 下位語辞書の例

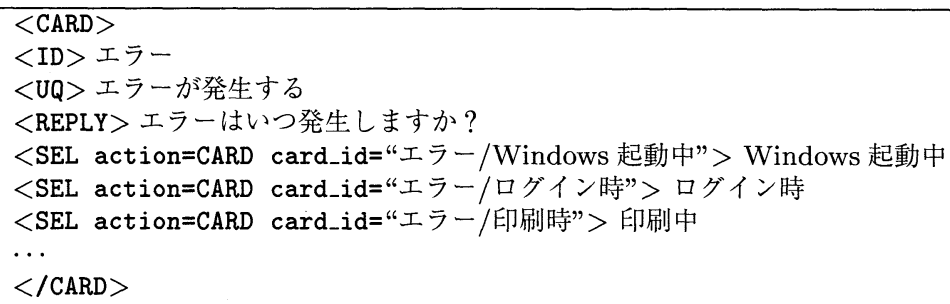

図 5 対話カードの例

- 対話カード (4.2節, 図 5)

曖昧なユーザ質問文のうち典型的なものに対して，どのような聞き返しを行うかを記述 したカードを利用する。 
ダイアログナビの内部の処理と，ユーザとの対話の関係を図 6に示す．基本的な流れは，対 話カードに基づくユーザとの対話によってユーザの質問が具体化され (図 6の左側のループ)，具 体化された質問によって知識ベースが検索され (右側の処理へ移行)，検索結果が自動編集され 選択肢の形でユーザに提示される。ユーザの最初の質問が具体的な場合は，対話カードとはマッ チせずに右側の処理へ移行し，はじめから知識べースの検索結果が提示される.

図 6中の各モジュールの働きは以下の通りである (詳細は次節以降に示す).

- 入力解析モジュール

質問文を 3 種類の質問タイプ (Symptom 型, How 型, What 型) に分類し, 質問文の内 容表現を抽出する。さらに，構文解析，キーワードと同義表現の抽出などを行う.

・ テキスト検索モジュール

対話カードおよび知識ベース (以下，これらを総称してテキストという) とユーザ質問文 のマッチングを行い, スコアの高いテキストを返す。マッチングの際には, 同義表現辞 書, 上位・下位語辞書を用いて表現のずれを吸収する.

- 状況説明文抽出モジュール

知識ベース中のユーザ質問文とマッチした文の, マッチした部分の周囲を抽出すること によって，ユーザにとって簡潔でわかりやすい選択肢を提示する.

\section{3 テキストの検索}

質問応答システムにおいてまず重要なことは，質問の答えを含むと思われるテキストを十分 な精度で検索できることである。そのために，質問タイプとプロダクト名による知識ベースの 絞り込みを行う。また，表現のずれを吸収するために同義表現辞書 (図 3) を利用したマッチン グを行う。さらに，スコア計算において,「ファイル ことによって，検索の精度を向上させる (Zhai, Tong, Milic-Frayling, Evans 1996).

\section{1 マッチングの前処理}

ユーザ質問文とテキスト内の文 (以下，テキスト文という) は，それぞれ構文解析を行って 文節単位の係り受け構造に変換した上でマッチングを行う。この節では，マッチングを行うま での前処理についてまとめる.

\subsection{1 構文解析とキーワード抽出}

ユーザ質問文とテキスト文の両者について，JUMAN(黒橋，長尾 1999)，KNP(Kurohashi and Nagao 1994) によって構文解析を行い, 各文節に含まれるキーワードを抽出する.JUMAN

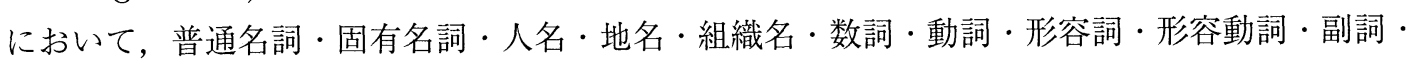




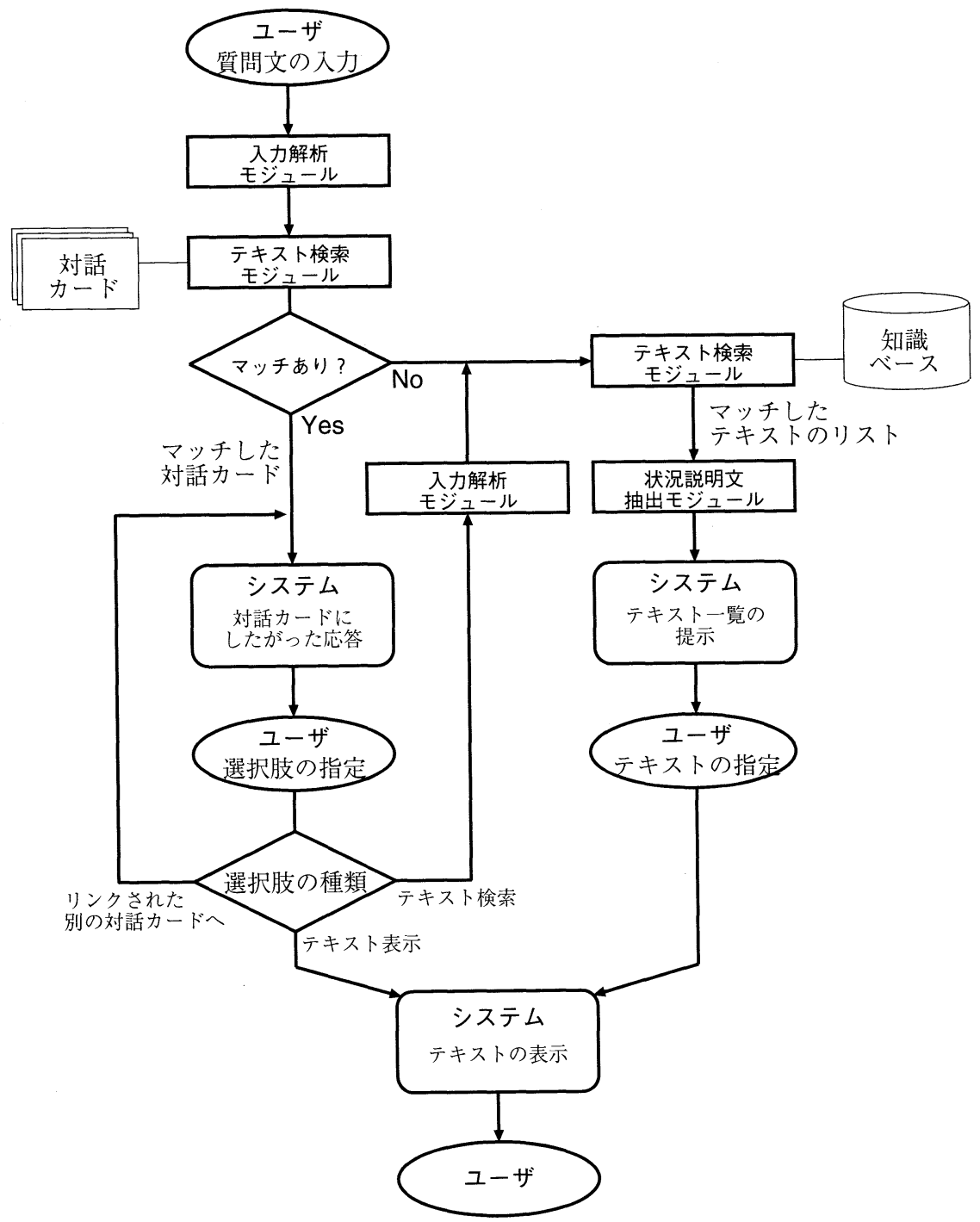

図 6 ダイアログナビのフローチャート

カタカナ・アルファベットと解析された語の原形をキーワードとみなす。ただし，一般的な語 彙「する」「ある」「行う」「おこなう」「行く」「いく」「なる」「下さる」「くださる」「ございま す」「できる」「出来る」は，キーワードとしない。 


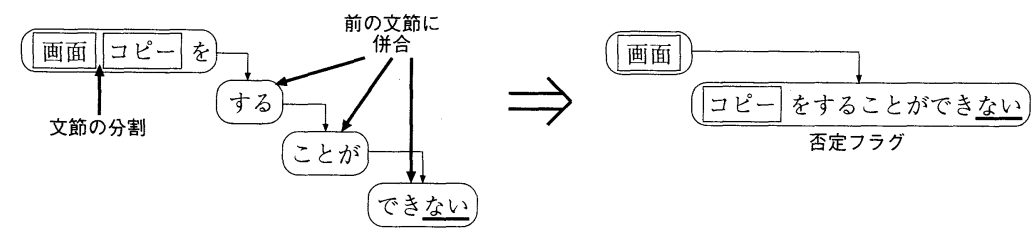

図 7 文節の分割・併合処理と否定フラグの付与

表 3 「話し言葉検索」の質問文タイプ

\begin{tabular}{|c|c|c|c|}
\hline 質問文タイプ & 説明 & 質問文の例 (文末表現パターン) & 割合 \\
\hline What 型 & $\begin{array}{l}\text { 局語の意味や定義などをたずねる } \\
\text { 質問 }\end{array}$ & $\begin{array}{l}\text { 〜て何ですか, 〜の説明をして, } \\
\text { 〜の意味を教えて }\end{array}$ & 約 $10 \%$ \\
\hline How 型 & 操作の方法などをたずねる質問 & $\begin{array}{l}\text { 〜方法を教えて, 〜にはどうした } \\
\text { らいいの，〜の使い方 }\end{array}$ & 約 $35 \%$ \\
\hline Symptom 型 & $\begin{array}{l}\text { 遭遇している問題や症状を述べ, } \\
\text { その解決策をたずねる質問 }\end{array}$ & $\begin{array}{l}\text { 〜してしまう, 〜が使えません， } \\
\text { 〜ができない }\end{array}$ & 約 $50 \%$ \\
\hline その他 & $\mathrm{C}_{\mathrm{C}}$ & 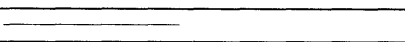 & 約 5\% \\
\hline
\end{tabular}

\subsection{2 文節の分割・併合処理}

マッチングのスコアを計算する際，KNP が出力した文節をそのまま用いることには問題が ある．例えば,「画面をコピーできない」は 2 文節,「画面コピーをすることができない」は 4 文 節と解析されるが，両者は同じことを表現している。これを適切に扱うためには，両者の単位 をそろえる必要がある。

本システムは，下記のルールに従って文節を分割・併合する (図 7).

（1）複数のキーワードを含む文節は，1キーワード毎に分割する. 分割された隣り合う文 節同士は，係り受けの関係にあるものとする。ただし，カタカナ語・アルファベット . 数詞が隣接している箇所では分割しない.このような語同士が隣接する場合は,「ウィ ンドウズ $98 \mathrm{SE}$ のようにプロダクト名などを表していることが多いからである.

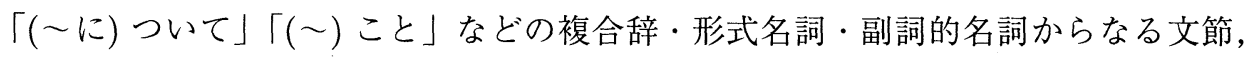
キーワードを含まない文節は，直前の文節に併合する。

\subsection{3 否定フラグの付与}

ユーザ質問文とテキスト文のマッチングの際に否定表現のバリエーションを吸収するため に，文節にフラグを付与する，具体的には，形容詞「ない」，助動詞「ぬ」，または形容動詞 「不可能た」を含む場合に否定フラグを付与する (図 7右).

\subsection{4 ユーザ質問文のタイプ推定と文末表現の削除}




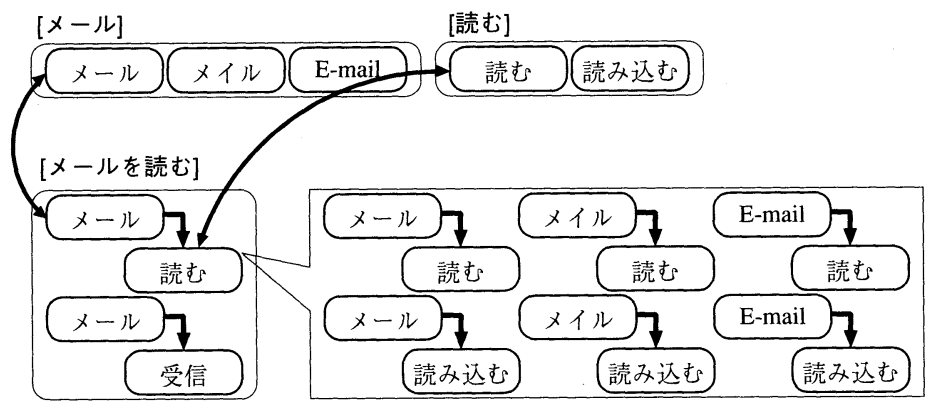

図 8 同義表現辞書の再帰的展開

「話し言葉検索」の検索ログを分析した結果，表 3 に示すようにユーザの質問には主に 3 つ のタイプが存在することがわかった．本システムでは，表3の文末表現パターンを用いて，ユー ザ質問文の質問タイプ (What 型，How 型，Symptom 型，タイプなしのいずれか) を推定する. また，文末表現パターンのうち,「〜って何ですか」「〜方法を教えて」のようにテキスト検索に おいてノイズとなるものについては，ユーザ質問文から削除する.

\section{2 表現のずれの吸収}

適切なテキストを検索するためには，ユーザ質問文とテキストの間の表現のずれが大きな問 題となる、本システムでは, 同義表現辞書と上位・下位語辞書を用いることによってこの問題 に対処する。

\subsection{1 同義表現辞書}

表現のずれは語のレベルだけでなく,「パソコンを起動する」「Windows を起動する」「電源 を入れる」のように，2文節以上のフレーズレベルにおいても多数存在する. そこで, 同義語だ けでなくフレーズレベルのものも含んだ同義表現をグループ化した同義表現辞書を作成し，こ れを用いて同義表現のマッチングを行う。

同義表現辞書の例は図 3 に示した。本辞書の作成は,「話し言葉検索」のログを解析し, 頻出 する同義表現をグループ化することによって行った。 また，和語動詞（「戻る」など）の可能形 (「戻れる」) や読み (「もどる」「もどれる」) も同義表現として登録した.

なお，同義表現辞書には再帰的な関係が含まれているため，これをあらかじめ展開しておく. 図8においては,「メールを読む」には 2 つのキーワード「メール」「読む」が含まれるが,「メー ル」には同義語「メイル」「E-mail」が存在し,「読む」には同義語「読み込む」が存在する。こ の場合,「メールを読む」というフレーズを $3 \times 2=6$ 通りに展開する.

マッチングの際には, ユーザ質問文とテキストの両者について, 同義表現辞書を調べて, そ 


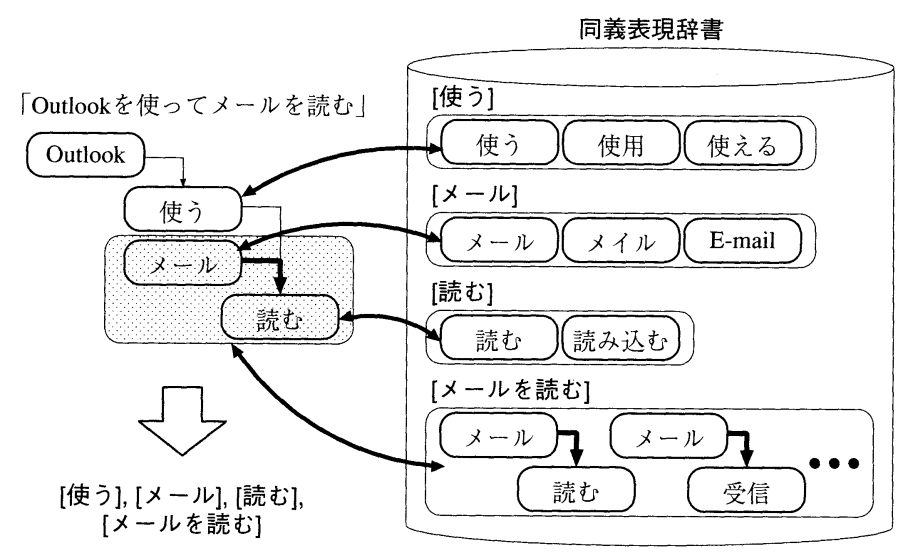

図 9 ユーザ質問文と同義表現辞書の照合

こに含まれる同義表現グループを抽出し, 同一グループのものがあればマッチするとみなす。た だし，3.3節で述べるように，テキストについてはあらかじめ同義表現グループを抽出しておく.

図 9に，ユーザ質問文と同義表現辞書の照合の例を示す。この例では，4つの同義表現グルー プ [使う], [メール], [読む], [メールを読む] が抽出される.

\subsection{2 上位・下位語辞書}

同義表現辞書ではうまく扱えない表現のずれも存在する．例えば,「ブラウザ」

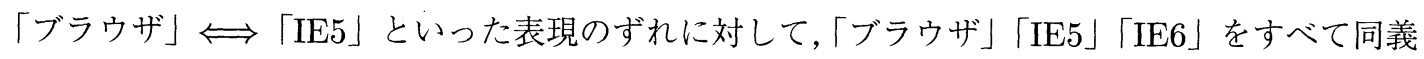
語として扱うことは問題である。なぜなら,「IE5」に関する質問に対して,「IE6」に関するテキ ストを示すことは適切でないからである.

そこで，図4に示すような上位・下位語辞書を作成し，テキストに現れるキーワードの上位 語・下位語を，キーワードと同様に扱うことによってこの問題に対処する．例えば,「IE6」が テキストに現れる場合はその上位語「IE」「ブラウザ」もキーワードとして扱い,「IE」がテキ ストに現れる場合はその上位語「ブラウザ」と下位語「IE3」「IE4」「IE5」「IE6」もキーワー ドとして扱う。ユーザ質問文についてはこの扱いを行わないことによって,「IE5」と「IE6」が マッチすることが避けられる。

\section{3 転置インデックスの利用}

テキストを高速に検索するために，前もってテキストからキーワード・同義表現グループの 抽出と, キーワードの上位・下位語の展開を行い, 転置インデックスを作成しておく.

本システムは，ユーザ質問文から抽出されたキーワードと同義表現グループについて転置イ 
表 4 質問タイプによるテキスト集合の絞り込み

\begin{tabular}{|c|c|c|c|c|c|}
\hline \multirow{2}{*}{\multicolumn{2}{|c|}{ テキスト集合 }} & \multicolumn{4}{|c|}{ 質問タイプ } \\
\hline & & \multicolumn{4}{|l|}{ What 型 } \\
\hline 用語集 & (What 型) & $o$ & & & $\mathrm{o}$ \\
\hline ヘルプ集 & (How 型) & o & o & & $\mathrm{o}$ \\
\hline \multirow[t]{3}{*}{ サポート技術情報 } & (Symptom 型) & o & & $\mathrm{O}$ & o \\
\hline & (How 型) & o & o & & o \\
\hline & (タイプなし) & $\mathrm{o}$ & 0 & o & o \\
\hline
\end{tabular}

ンデックスを参照し，1 個以上のキーワードまたは同義表現が一致するテキストを，次節で述 ベる質問タイプ・プロダクト名による絞り込みの対象とする.

\section{4 知識ベースの絞り込み}

テキスト検索の精度を向上させるために，質問タイプとプロダクト名による知識ベースの絞 り込みを行う。

\subsection{1 質問タイプによる絞り込み}

テキスト検索モジュールは, 入力解析モジュールによって推定された質問パターンにもとづ いて，表 4 に示すようにテキスト集合を絞り込む. 原則として，用語集はWhat 型，ヘルプ集 はHow 型の質問に対応させる。サポート技術情報についてはSymptom 型・How 型を示すタグ が付与されているので，これを利用する.

なお，What 型の質問については必ずしも用語集を用いて答えればよいとは限らない. 例え ば,「コントロールパネルについて教えて」のような質問はWhat 型に分類されるが，用語の定 義ではなく操作方法などについて聞いていると解釈することもできる，よって，全てのテキス トを検索対象とした上で，複数の知識べースのテキストがユーザ質問とマッチした場合には用 語集のテキストを最初に提示する。

\section{4 .2 プロダクト名による絞り込み}

ヘルプ集・サポート技術情報については，図2に示したようにすべてのテキストに対象プロ ダクト名が明示されているので，これを利用してテキストの絞り达みを行う.

質問文にプロダクト名 (Windows NT, Word, Excel など) が出現する場合は，そのプロダ クトを対象とするテキストを検索対象とする。質問文に複数のプロダクト名が出現する場合 （「Excel で作った表が Word で読み込めない」など）は，いずれかのプロダクトを対象とする テキストを検索対象とする. 


\section{5 テキストのスコア計算}

転置インデックスを参照して得られ，さらに質問タイプ・プロダクト名によって絞り达まれ た各テキストを対象として，ユーザ質問文との間で係り受け関係まで考慮した類似度計算を行 う。ただし，絞り込まれたテキスト数が 1000 個を超える場合は，転置インデックスにおいて一 致したキーワード・同義表現グループの数の多い順に，上位 1000 個までを対象とする.

\subsection{1 文類似度の計算}

ユーザ質問文とテキスト文の 2 文の類似度の計算は，3.1節で述べた文節を単位として行う。 2 文の互いに対応する文節と係り受け関係の割合 (被覆率) をそれぞれ計算し，その積を 2 文の 類似度とする。

まず，2 文間で，以下の条件によって文節・係り受け関係を対応づける。その際，対応する 文節・係り受け関係に対応度 $(0$ 以上, 1 以下の值) を付与する.

ユーザ質問文の文節 $\mathbf{A}$ に含まれるキーワードと, テキスト文の文節 $\mathbf{A}$ 'に含まれる キーワード(あるいはその上位・下位語) のいずれかが一致する場合， $\mathbf{A}$ と $\mathbf{A}$ 'を対応 づける。対応度は，以下のように計算する。

(a) $\mathbf{A} 、 \mathbf{A}^{\prime}$ に共通のキーワードが含まれる場合は, 以下の計算式によって対応度 を計算する。

$$
\text { (対応度 })=\frac{\text { (共通して含まれるキーワード数 })}{(\mathbf{A}, \mathbf{A} ’ \text { のちの多い方のキーワード数 })}
$$

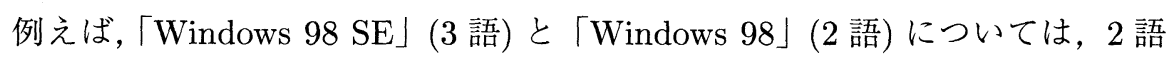
$\lceil$ Windows」「98」が共通して含まれるので，対応度は $2 / 3(\simeq 0.67)$ となる．た だし，多くの場合，文節は 1 キーワードのみを含むので，対応度は 1.0 となる。

(b) Aのキーワードと, A'のキーワードの上位語または下位語が一致する場合は, 対応度は 0.9 とする。

(c) $\mathbf{A}$ と $\mathbf{A}$ 'の否定フラグが一致しない場合は, 対応度は一致する場合の 0.6 倍と する.

（2） ユーザ質問文内の係り受け関係 $\mathbf{A} \rightarrow \mathbf{B}$ とテキスト文内の係り受け関係 $\mathbf{A}^{\prime} \rightarrow \mathbf{B}$ 'につ いて，文節 $\mathbf{A} 、 \mathbf{A}^{\prime}$ と文節 $\mathbf{B}, \mathbf{B}^{\prime}$ がそれぞれ対応する場合，それらを対応づける。 $\mathrm{A} \rightarrow \mathrm{B}$ の対応度は $\mathrm{A}, \mathrm{A}$ の対応度と $\mathrm{B}, \mathrm{B}$ の対応度の積とする.

（3） ユーザ質問文から抽出された同義表現グループとテキスト文から抽出された同義表現 グループが一致する場合, それらが抽出された文節・係り受け関係を対応づける (図 10). 対応度は 1.0 とする。

以上の処理の結果, 両者の文節・係り受け関係に対応度が付与される. 複数の対応を持つ文節・ 係り受け関係については，いずれか大きな対応度をその対応度とする. 


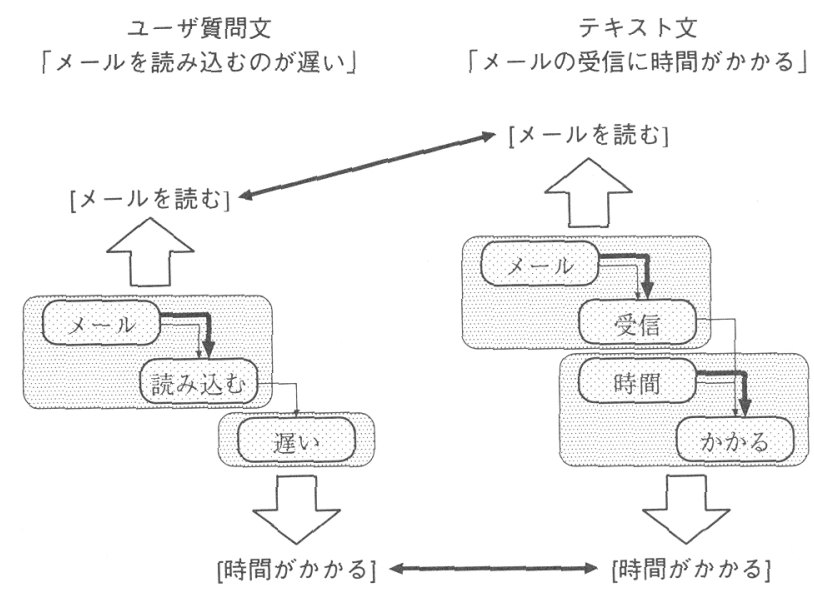

図 10 同義表現の対応づけ

ユーザ質問文，テキスト文の被覆率は，それぞれ以下の式によって計算する。

$$
(\text { 被覆率 })=\frac{(\text { 文節の対応度の和 })+(\text { 係り受け関係の対応度の和 }) \times 2}{(\text { 文節の総数 })+(\text { 係り受け関係の総数 }) \times 2}
$$

ユーザ質問文，テキスト文の両者の被覆率の積を，両者の類似度とする。

図 11 に扔いては，ユーザ質問文，テキスト文ともに 3 つ文節と 2 つ係り受汁関係が対 応を持っており，対応度はすべて 1.0 である。両者の被覆率はそれぞれ $1.0,0.54$ であので， 類似度は 0.54 となる。

\subsection{2 テキストのスコアと代表文}

各テキスト中でもっとも類似度の大きな文をテキストの代表文とし，その類似度をテキスト のスコアとする。

\subsection{3 サポート技術情報の扱い}

サポート技術情報は，表 2 に示したようにテキスト全体の複数文がマッチングの対象となる ため，特別な扱いをしている。

・ テキスト文の長さが一様ではないので，テキスト文の被覆率を考慮しない。すなわち， ユーザ質問文とテキスト文の類似度は，ユーザ質問文の被覆率とする。

-一つの事象を複数文で説明している場合が多いので，前後の文とのマッチングを考慮す る。ユーザ質問文とテキスト文 $S_{n}$ の間で類似度を計算する場合は，ユーザ質問文の文 節・係り受计関係と, $S_{n}$ の前後の文 $\left(S_{n-1}, S_{n+1}\right)$ の文節・係り受け関係の対応にも, 対応度 0.5 を与える。 


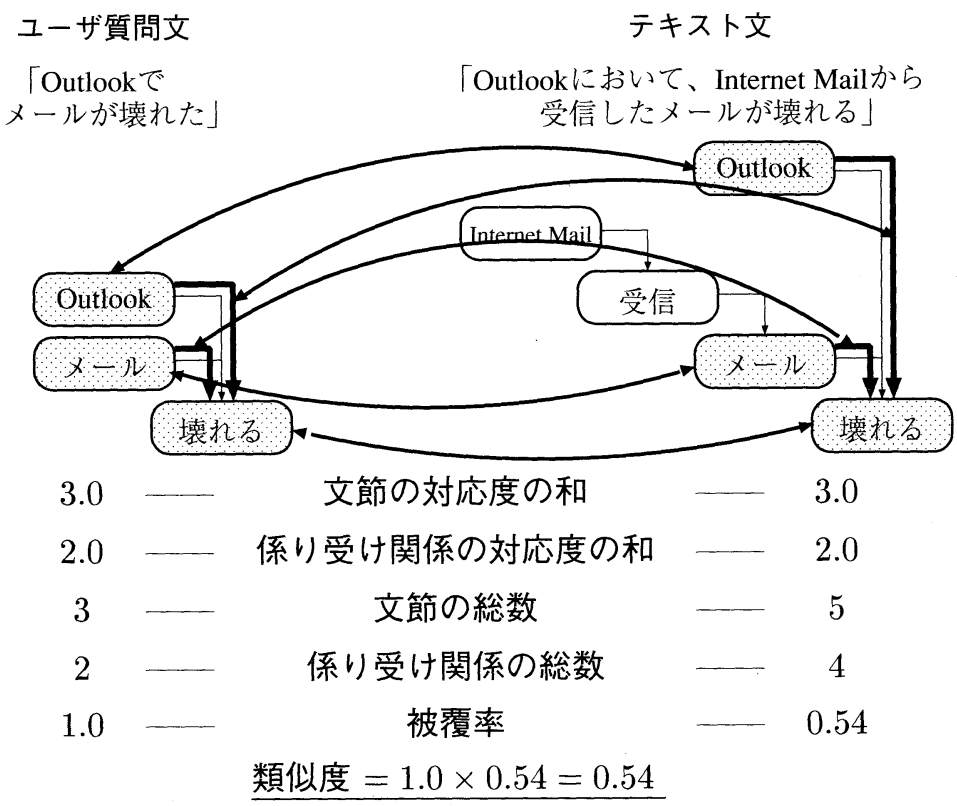

図 11 ユーザ質問文とテキスト文の対応づけと類似度の計算

・ サポート技術情報のテキストには，図 2 に示したように，セクションが存在する。これ らのセクションのうち,「タイトル」「概要」「現象」「症状」セクションには, ユーザが頻 繁に質問することがらが書かれていることが多い.そこで，文の存在するセクションに 応じて，類似度に下記の係数を掛け合わせる。

$$
\begin{array}{ll}
\text { - タイトル・概要 } & 1.0 \text { 倍 } \\
\text { - 現象・症状 } & 0.8 \text { 倍 } \\
\text { - 上記以外 } & 0.6 \text { 倍 }
\end{array}
$$

\section{6 選択肢の絞り込み}

テキスト検索モジュールは，3つのテキスト集合 (用語集・ヘルプ集・サポート技術情報) ご とに，テキストのスコアに基づいてユーザに提示する選択肢を絞り込む.

テキストをスコアの大きい順に整列し，上位 $n$ 個までをユーザに提示する選択肢とする．た だし，スコアが閾値 $t$ を回るものは対象外とする。また，同じスコアの複数のテキストが $n$ 位前後で並ぶ場合は，それらをすべて含める， $n, t$ の值は，表 5 に示すようにテキスト集合ご とに定めた。

複数のテキスト集合から選択肢が得られた場合は, 用語集，ヘルプ集，サポート技術情報の 
表 5 選択肢の絞り込みのパラメータ

\begin{tabular}{c|cc}
\hline & 最大選択肢数 & スコア閾值 \\
テキスト集合 & $n$ & $t$ \\
\hline 用語集 & 2 & 0.8 \\
ヘルプ集 & 5 & 0.3 \\
サポート技術情報 & 10 & 0.1 \\
\hline 対話カードの<UQ>(4.2節 $)$ & 1 & 0.8 \\
\hline
\end{tabular}

順で提示する。

\section{4 ユーザのナビゲート}

ユーザが自分の知りたいことを普通に表現しても，それで一意に適切なテキストが決まるこ とは少ない. 例えば「Windows98で起動時にエラーが発生した」という比較的具体的な質問で あっても，いくつかの原因と対策があり，それぞれにテキストが存在する．ユーザの質問がさ らに曖昧であったり抽象的であったりする場合には，より多くのテキストが候補として選ばれ る、いずれにせよ, ユーザが, 複数のテキスト候補の中から, 自分の状況に一番適切なものを 選択することが必要になる。

WWW のサーチエンジンは，テキスト中から検索語を含む部分を抽出してユーザに提示す ることによって，ユーザのテキスト選択を補助している. 本システムでは，この考え方を一歩 進め，ユーザの質問 (遭遇している問題)をより具体化するような説明文をテキスト中から自動 的に抽出し，それらを選択肢として提示するという形でユーザへの聞き返しを行う.

しかし，ユーザの質問が非常に曖昧な場合には上記の方法はうまく機能しない。そこで，頻 繁に尋ねられる曖昧な質問に対して，それをどのように対話的に具体化するかを対話カードと いう形式で体系化した。例えば，図 12 に示すように，ユーザが「エラーが発生した」という質 問をした場合,「エラーが発生したのはいつですか」「使っているWindows のバージョンは何で すか」などの聞き返しを行って，ユーザの問題を具体化する.

\section{1 状況説明文の抽出}

ユーザ質問とマッチした知識ベース中の文では，その中のマッチしなかった部分に，ユーザ の問題をより具体化する状況説明が与えられていると考えられる(このような部分を状況説明 文とよぶ). たとえば，ユーザが「ページ違反が発生する」と質問し，これが「IE5を起動した 際にページ違反が発生する」という文にマッチした場合，マッチしていない「IE5を起動した 際に」という部分が状況説明文となる.ユーザの質問にマッチした複数の文からそれぞれ状況 説明文を抽出し，ユーザに選択肢として提示すれば，ユーザは自分の状況に適合するものを容 


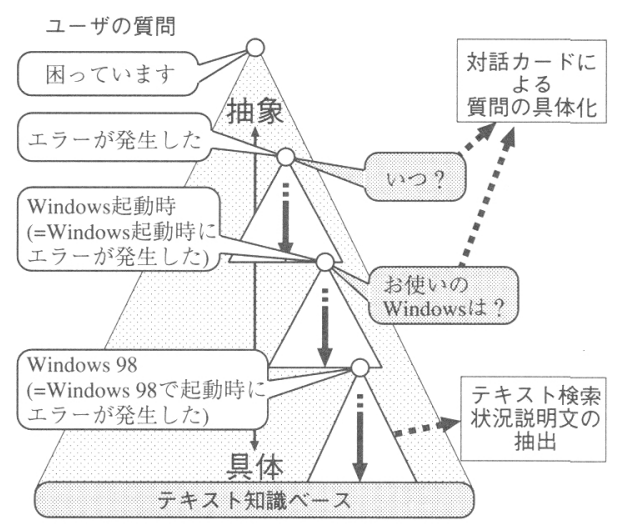

図 12 ユーザのナビゲート

易に選択することが可能となる。

状況説明文抽出のアルゴリズムを以下に示す。

（1）「この資料では， ( )」「以下の」「(〜する) 問題について説明しています」など，頻 出する冗長な表現をパターンマッチにより削除する。

（2）文を次の箇所で分割寸る。分割された各部をセグメントと呼ぶ.

- 連用修飾節

- 「〜とき」「〜際」「〜場合」「〜最中」など

- 読点を伴うデ格

（3） セグメントのうち，すべての文節がユーザ質問文中の文節と対応するものを削除する (同義表現として対応する文節も含む).

（4）末尾(削除されたセグメントを除く)のセグメントを状況説明文の核とする.

（5）核のセグメントと，それに直接係るセグメントのみを，状況説明文として選択する。

アルゴリズムの適用例を図 13 に示す。まず，左の文は 2 つのセグメント $\mathbf{A} ・ \mathbf{B}$ ，右の文は 3 つのセグメント $\mathrm{C} ・ \mathrm{D} ・ \mathrm{E}$ に分割される。このうち, 左の文のセグメント $\mathrm{B}$ と, 右の文のセグ メント $\mathrm{C} ・ \mathrm{E}$ は，すべての文節がユーザ質問文と対応するため削除される。結果としてセグメ ント $\mathbf{A}$ と $\mathbf{D}$ が状況説明文の核となり,「IE5を起動した際に」と「タスクスケジューラを使う と」が状況説明文として出力される。

サポート技術情報のテキストについては，各選択肢テキストの代表文から状況説明文を抽出 する。用語集・ヘルプ集のテキストについては, 各テキストの見出し語・タイトル自体が簡潔 な説明文となっているので，この処理の対象とはしない。 


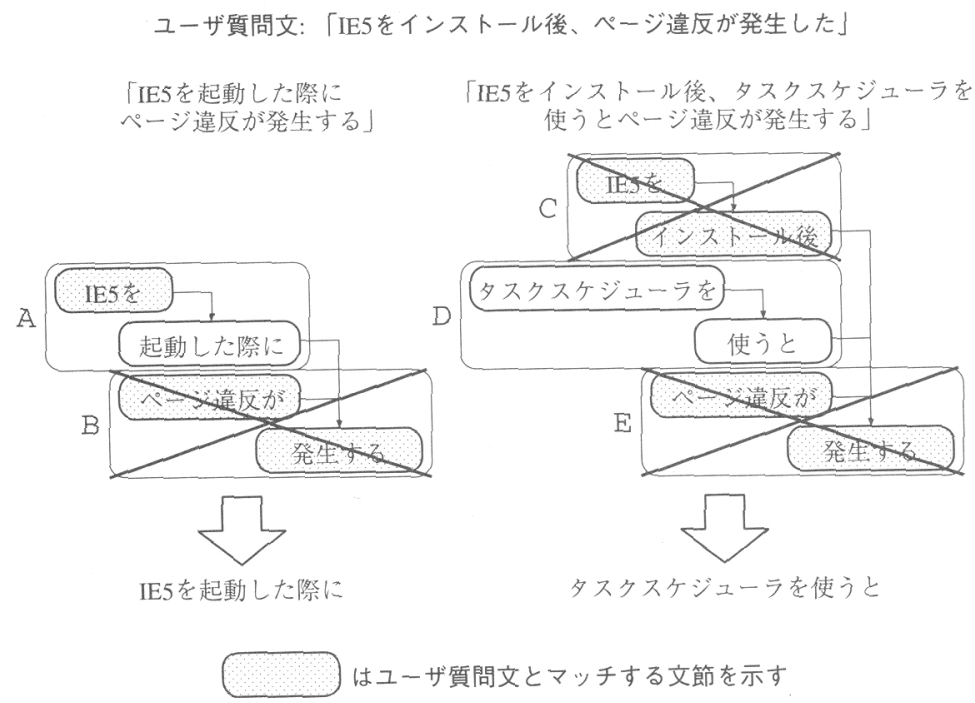

図 13 選択肢テキストからの状況説明文の抽出

\section{2 対話カードを用いた聞き返し}

ユーザの質問が非常に曖昧な場合には，テキスト検索の精度が低くなり，多くの不適切なテ キストがマッチしてしまう。このような場合に状況説明文の抽出を行っても，誤りを含んた多 くの選択肢が得られることになり，ユーザの助けとはならない。

そこで，頻繁に尋ねられる曖昧な質問に対して，それを対話的に具体化する手順を対話カー ドという形式で体系化した。1枚の対話カードは，あるユーザ質問に対して，どのような聞き 返しをすればよいかを記述したもので, 以下の要素から構成されている(図 5).

<ID>：対話カードのID.

〈UQ>： ユーザ質問文。この部分がユーザの質問文とマッチすればこの対話カードが利用さ れる。

$<$ REPLY $>$ ： システムからユーザへの聞き返し発話.

$<$ SEL action=CARD/SHOW/RET ... > : 聞き返しの際, ユーザに提示する選択肢。それ ぞれの選択肢にはユーザがそれを選んだ場合のシステムの動作が記述されている。 action=CARDの場合には card_id=で示された対話カードに移る。 action=SHOWの場合 には urlで示された webページ(マイクロソフトのサイトの種々のドキュメント)または text_idで示された知識ベースのテキストを表示する。action=RETの場合にはphrase で示された質問文によって知識ベースを検索する。

対話カードの利用例を図 1によって説明する。まずユーザが「エラーが発生した」という質問 をすると，質問文と各対話カードのくUQ>の部分とのマッチングを 3 節で述べたアルゴリズムに 
よって行う.この結果, 図 5上段の対話カードが選ばれる.システムはこのカードに従って,「エ ラーはいつ発生しますか?」という聞き返しを，選択肢を示して行う．ユーザが「Windows 起動 中」を選ぶと, システムは図 5 下段の [エラー/Windows 起動中] の対話カードに移って,「あな たがお使いの Windows を選んでください」という聞き返しを行う。ここでユーザが「Windows 98」を選ぶと,「Windows 98 の起動中にエラーが発生する」を質問文として知識べースのテキ ストの検索を行う。

対話カードはこのように階層的に構成されており, そのすべてのカードの <UQ $>$ が検索対象 となっている。すなわち, 図 $12 て ゙$ 示したさまざまなレベルの曖昧性・抽象度の質問を全体的に カバーするように設計されている。たとえば，ユーザが「Windows 起動中にエラーが発生す る」と質問した場合には，はじめから図5下段のカードを用いた対話が行われることになる.

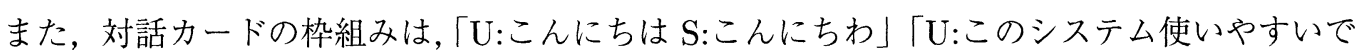
すね S:ありがとうございます」のようなドメインとは関係のない例外的な対応を行う場合にも 利用している (この場合はＳSEL>のないカードとなる).このような対応ができなければ, 通常 の検索，すなわち知識ベースに対して「このシステム使いやすいですね」で検索を行ってしま い,「システム」や「使う」を含む知識ベースを提示するということが起こってしまう。ユーザ の例外的な発話に対する不適切な動作を防ぎ, 正常な対話を維持するという意味で, 対話カー ドによる例外処理は重要である(このような例外的な対話は次節では「範囲外」の対話と扱って いる).

\section{5 評価}

ダイアログナビは, http://www.microsoft.com/japan/navigator/において, 2002 年 4 月から公開サービスを行っている. ユーザとの質問応答のログは, 対話データベースとして蓄 積している。

本システムの評価としては, 対話セッションの評価, ユーザとシステムのふるまいの分析, 状況説明文の抽出結果が妥当かどうかの評価の 3 種類を行った。

\section{1 対話セッションの評価}

対話データベース中の 2002 年 8 月 1 日〜 31 日の質問応答ログの中から無作為に 300 回のア クセスを選択した。 それらを人手によってタスク指向対話としての意味的まとまりに分割した. このまとまりを対話セッションとよぶ. 結果として, 378 個の対話セッションが得られた. 1 対 話セッション当たりの発話ペア (ユーザのキーボード入力またはマウスでの選択と, それに対す るシステムの応答) の回数は, 平均 1.42 回であった.

378 対話セッションそれぞれに対して, 評価者 1 名が次のいずれかの評価を与えた. 
成功:知識あり システムが少なくとも 1 つの適切なテキストを選択肢として提示した.

成功:知識なし 知識ベースに適切なテキストがなく，かつシステムが「該当する情報を見つ けることができませんでした」と回答した。

失敗:知識あり 知識ベースに適切なテキストがあるにもかかわらず，システムがそれらのう ちどれも選択肢として提示することができなかった。

失敗:知識なし 知識ベースに適切なテキストがないにもかかわらず，システムが不適切なテ キストを選択肢として提示した。

範囲外:適切 ユーザの質問は想定ドメインの範囲外であったが, システムは適切な応答をした。 範囲外:不適切 ユーザの質問が想定ドメインの範囲外であり，システムが不適切な応答をした。 本評価は，仮想的なテストセットによる評価とは異なり，実際にサービスを行った場面での システムのふるまいを正確にとらえている．しかし，不特定多数のユーザの真の意図に基づい て応答の適切さを判断することはできないという問題がある。そこで，対話セッションを以下 の 4 つのタイプに分類し，それぞれのタイプについての評価のガイドラインを以下のように定 めた上で評価を行った．評価の例を表 6 ～表 9 に示す.なお，表において，“U:”はユーザの発 話，“S:”はシステムの発話を示す。また，“○”は評価者が「適切なテキスト」と判断したテキ ストを示す.

・ タイプ A: ユーザの質問が具体的で，適切なテキストの特定に必要な情報がすべて指定 されている対話セッション (表 6$)$.

この場合は，ユーザが指定した情報がすべて含まれているテキストを，適切なテキスト であるとする。

システムが提示した選択肢中に適切なテキストが存在する場合 $(\mathrm{A}-1, \mathrm{~A}-2)$ は,「成功:知 識あり」とする，その他の場合は，評価者がキーワード検索システム 5 を用いて知識べー スを網羅的に検索し，適切なテキストが見つかれば「失敗:知識あり」(A-4, A-5), 見つ からなければ「成功: 知識なし」(A-3) または「失敗: 知識なし」(A-6) とする.

なお，ユーザがセッションの一部で曖昧な質問をしていても (A-2, A-4), セッション全 体として必要な情報がすべて指定されているときは，この夕イプとする.

・ タイプ B: ユーザの質問が曖昧で, 適切なテキストの特定に必要な情報が一部欠落して いる対話セッション (表 7). 対話カードが使用されたセッションは除く.

この場合は，ユーザの状況に完全に合致するテキストはどれかを判断することはできな いので，ユーザが与えた指定したすべての情報が含まれているテキストを，適切なテキ ストであるとみなす。

ユーザの質問が 1 単語のみである場合 (B-3，B-4) は，その単語が含まれるすべてのテキ ストを適切なテキストであるとみなす。

5 キーワード入力に対して, マッチするすべてのテキストを表示する評価用システム. 
表 6 対話セッション評価の例 (タイプ A)

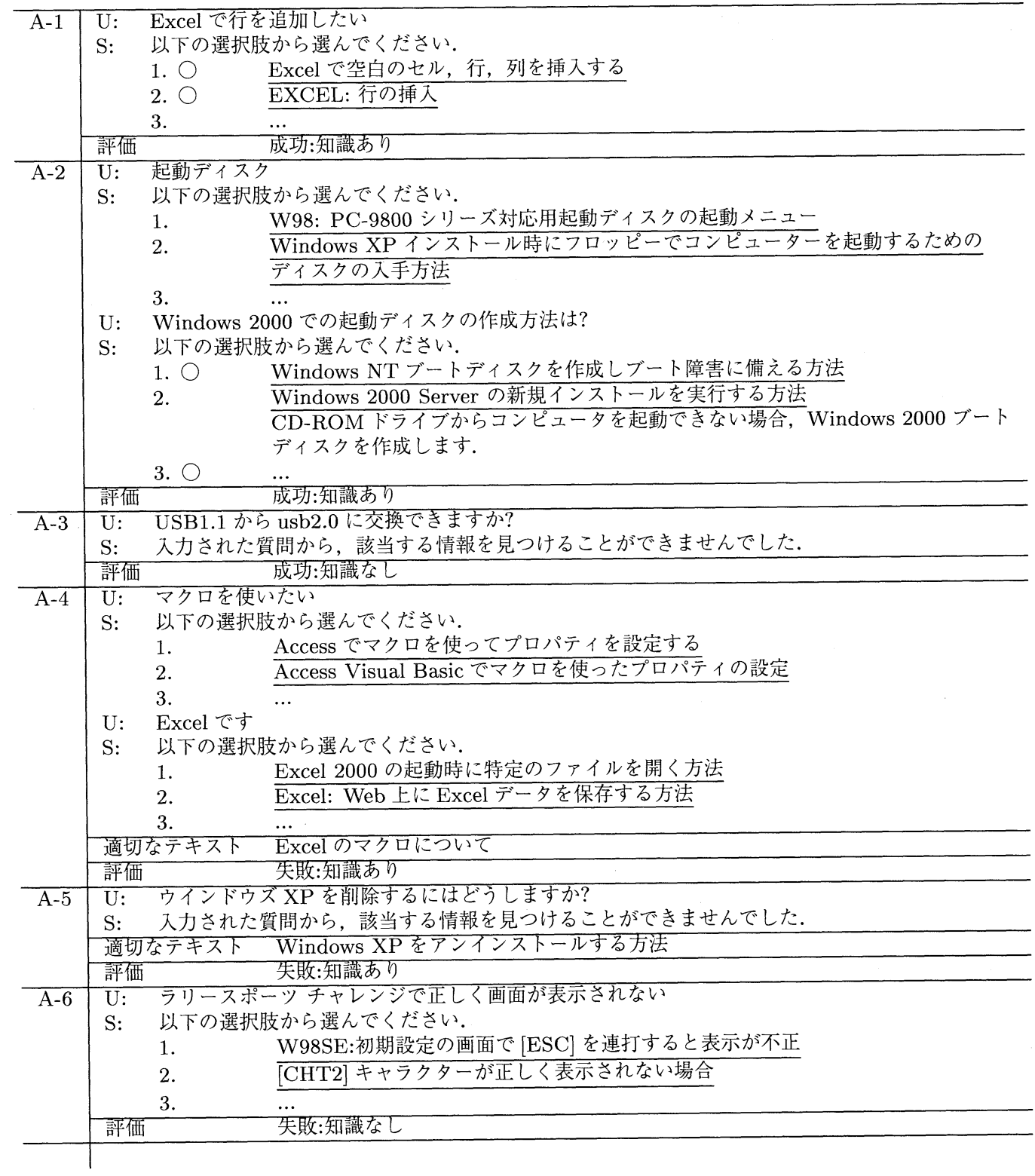

・ タイプ C: 対話カードが利用された対話セッション (表 8).

この場合は，対話カードの最も下の階層までユーザが選択肢を指定し，かつ適切なテキ ストまたは選択肢が提示された対話セッションを,「成功: 知識あり」と判断する(適切な テキストの判断基準はタイプ $\mathrm{A}$ に準ずる). 対話カードの作成の際には, 各々の選択肢に 
表 7 対話セッション評価の例 (タイプ $\mathrm{B}$ )

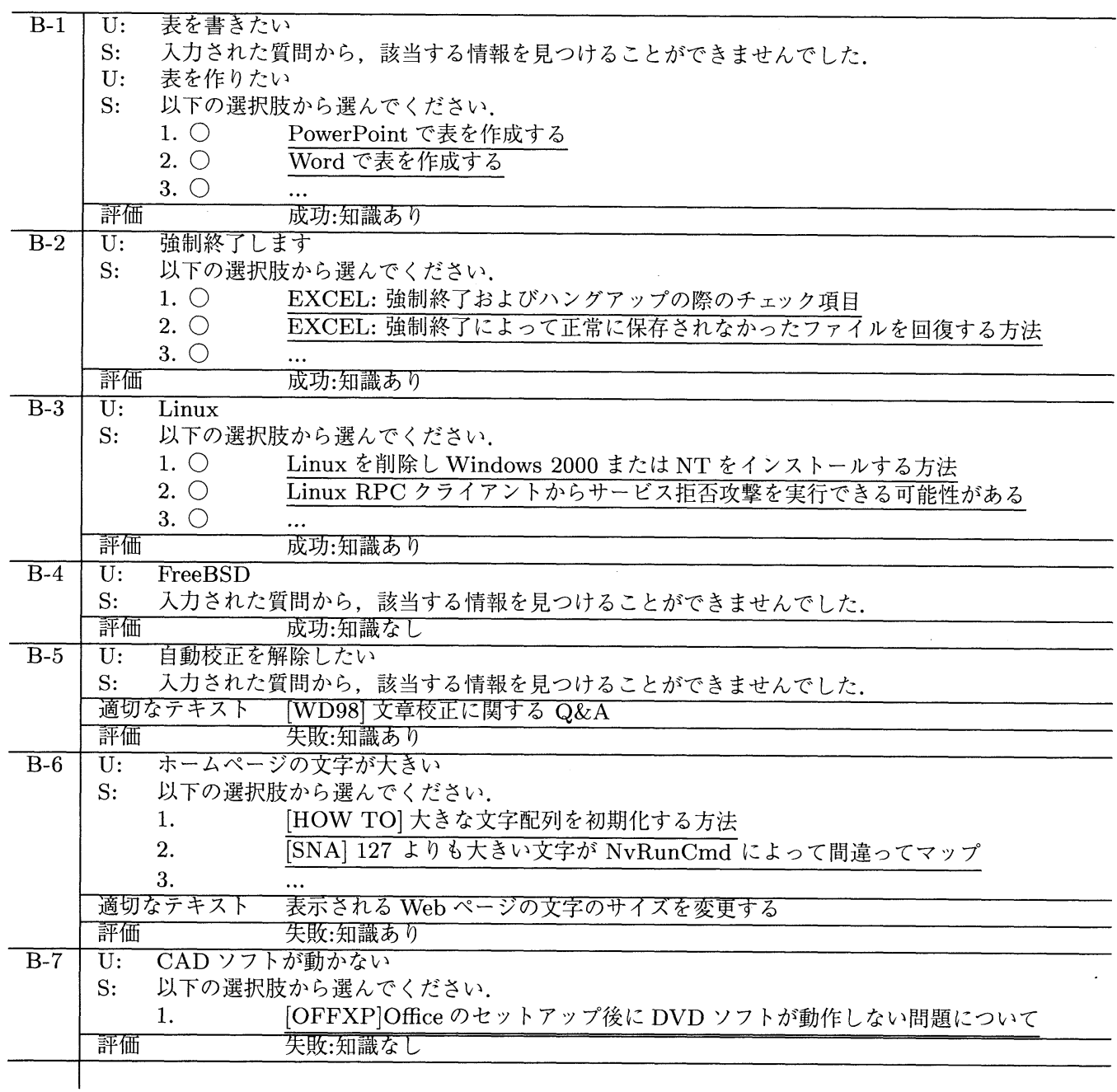

対応する質問文 (phrase) に対して適切なテキストが提示されるかどうかをチェックして いるので，適切なテキストが提示されないことはほとんどなかった。

・ タイプD: ユーザの質問が想定ドメインの範囲外である対話セッション (表 9). この場合は，対話カードを利用して応答したとき (D-1) と，テキストを検索した結果と して該当する情報がないと応答したとき (D-2) は「範囲外: 適切」，検索されたテキスト を提示してしまったとき (D-3) は「範囲外: 不適切」とした.

表 10の右側 (計の闌) に対話セッション評価の結果を示す．成功の割合は,「範囲外」を除い 
表 8 対話セッション評価の例 (タイプ C)

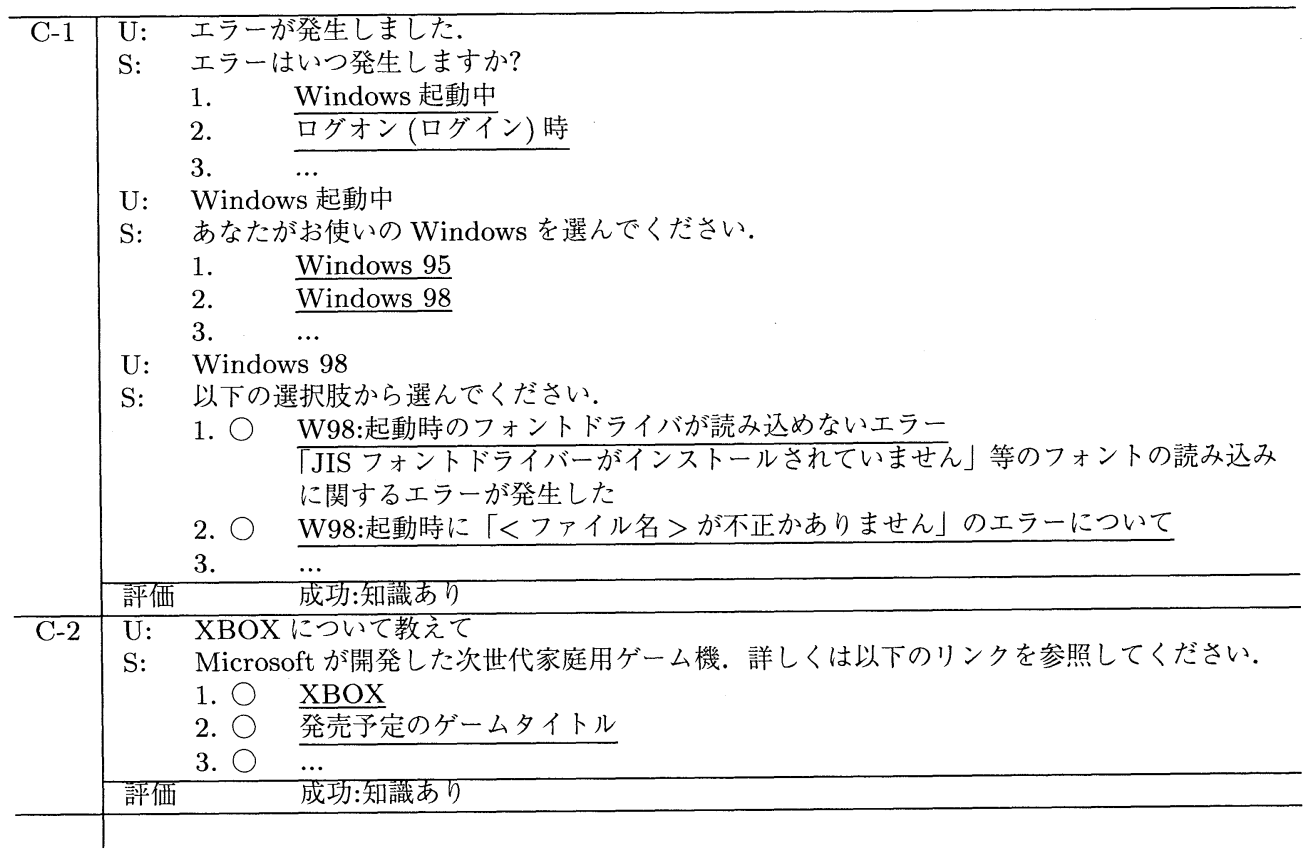

表 9 対話セッション評価の例 (タイプ D)

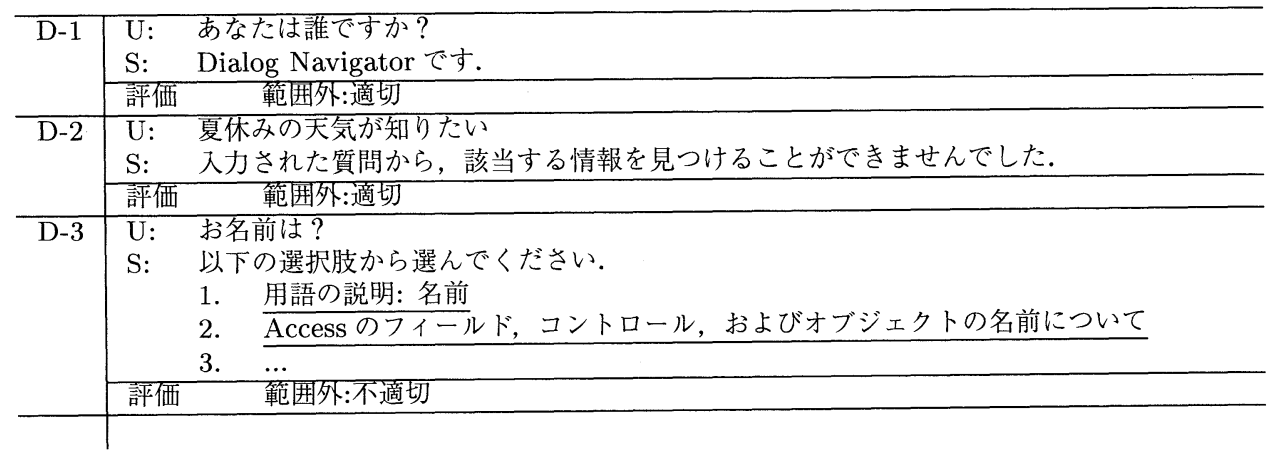

た 230 対話セッションのうち $75 \%$ であった.

対話セッション内において対話カードによって応答が行われたかどうかと, 対話セッショ ンの評価の関係を表 10 左側に示す。現在, 対話カードの枚数は 216 枚 (深さは最大で 3 階層) である。評価対象の対話セッション中，対話カードが利用された割合は，「範囲外」を除いて $17 \%(=38 /(38+192))$ であり, 対話カードが利用されたセッションの大部分は「成功」であっ 
表 10 対話カード利用の有無と対話セッション評価

\begin{tabular}{|c|c|c|c|c|}
\hline \multirow{2}{*}{\multicolumn{2}{|c|}{ 評価 }} & \multicolumn{2}{|c|}{$\begin{array}{l}\text { セッション内における } \\
\text { 対話カードによる応答 }\end{array}$} & \multirow[b]{2}{*}{ 計 } \\
\hline & & あり & なし & \\
\hline \multirow{3}{*}{ 成功 } & 知識あり & $38(100 \%)$ & $111(58 \%)$ & $149(65 \% /$ \\
\hline & 知識なし & $0(0 \%)$ & $25(13 \%)$ & $25(11 \%)$ \\
\hline & 計 & $38(100 \%)$ & $136(71 \%)$ & $174(76 \%)$ \\
\hline \multirow{3}{*}{ 失敗 } & 知識あり & $0(0 \%)$ & $15(8 \%)$ & $15(7 \% /$ \\
\hline & 知識なし & $0 \%)$ & $41(21 \%)$ & $41(18 \%)$ \\
\hline & 計 & $0 \%)$ & $56(29 \%)$ & $56(24 \%)$ \\
\hline \multicolumn{2}{|c|}{ 小計 (範囲外を除く) } & $38(100 \%)$ & $192(100 \%)$ & $230(100 \% /$ \\
\hline \multirow{3}{*}{ 範囲外 } & 適切 & $57(\longrightarrow)$ & $0(-)$ & $57(-1$ \\
\hline & 不適切 & $3(-)$ & $88(-)$ & $91(-1$ \\
\hline & 計 & $60(-)$ & $88(-)$ & $148(-/ 39 \%)$ \\
\hline \multicolumn{2}{|c|}{ 合計 } & $98(-)$ & $280(-)$ & $378(-/ 100 \%)$ \\
\hline
\end{tabular}

た。また，範囲外の質問に対しても対話カードでカバーされている範囲ではほぼ適切に対応で きており，全体として対話カードという枠組みは有効に機能していると考えられる.

対話セッションの失敗の最も大きな原因は, 知識ベース, 同義表現辞書の不足である.ユー ザ質問文に対して適切なテキストが存在しない場合，A-3 のように適切なテキストがないこと を判断するのは難しく, A-6・B-7 のように䛊ることが多い. かりに, 表 5 のスコア閾値 $t$ を大 きくすればこの失敗を減らすことはできるが, その代償として適切なテキストが存在する場合 の「成功:知識あり」が減って,「失敗:知識あり」が増えてしまう.A-5・B-6のような「失敗:知 識あり」を減らすには，同義表現辞書をより充実させ，適切なテキストを大きなスコアでマッ チさせる必要がある。

また，A-4のように，対話のコンテキストを考慮していないために失敗した対話セッション もあった。この種の失敗を減らすには,コンテキストを考慮したテキストの検索を行う必要が ある。

なお，同義表現辞書と，例外処理的な対話カードについては，対話データベースで顕著な ものについて随時デー夕の修正・作成を行っている。このことによって, 公開当初の成功率は $60 \%$ 程度であったが，徐々に改善され，現在では表 10で示したとおり $70 \%$ を越える成功率と なってきている。

\section{2 ユーザとシステムのふるまいの分析}

前節で述べた 378 対話セッション内において，ユーザがどのような行動をしたか，システム がそれに対してどのような応答を行ったかを調べた (図 14).

ユーザの質問文の入力 (518 回) のうち, 対話カードによって応答されたものは $19 \%(=$ 


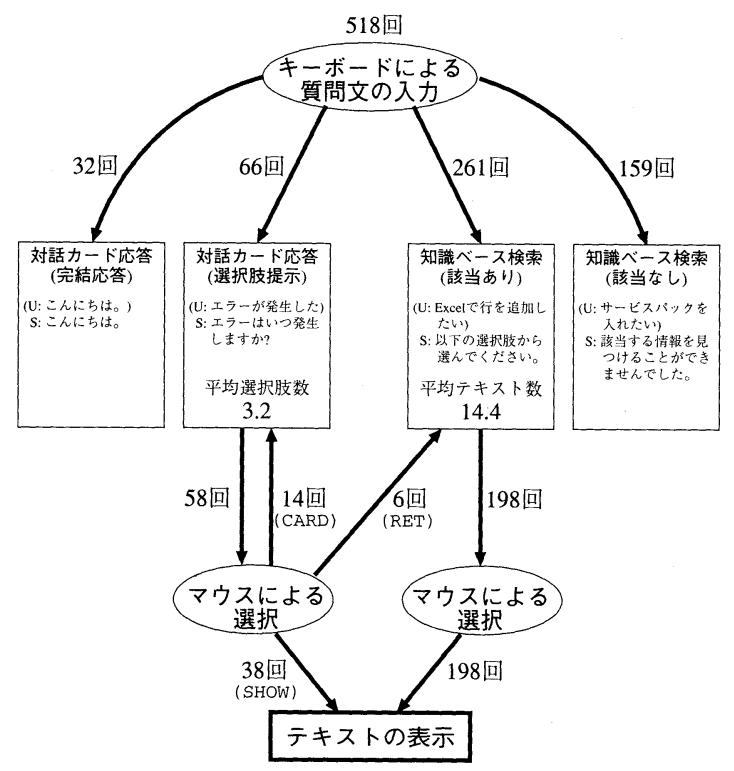

図 14 ユーザ行動とシステム応答の回数分布

表 11 ユーザ質問文の長さとシステム応答の関係

\begin{tabular}{|c|c|c|c|c|c|c|}
\hline \multirow[b]{2}{*}{ 質問文の長さ } & \multicolumn{3}{|c|}{ 対話カード応答 } & \multicolumn{2}{|c|}{ 知識ベース検索 } & \multirow[b]{2}{*}{ 計 } \\
\hline & 完結応答 & 選択 & 支提示 & 該当あり & 該当なし & \\
\hline 1 文節 & $29(13 \%)$ & 17( & $8 \%)$ & $115(52 \%)$ & $59(27 \%)$ & $220(100 \%)$ \\
\hline 2 文節 & $3(2 \%)$ & 37( & $28 \%)$ & $46(35 \%)$ & $47(35 \%)$ & $133(100 \%)$ \\
\hline 3 文節 & $(\quad)$ & 10( & $14 \%)$ & $33(45 \%)$ & $30(41 \%)$ & $73(100 \%)$ \\
\hline 4 文節 & ) & 2( & $6 \%)$ & $22(65 \%)$ & $10(29 \%)$ & $34(100 \%)$ \\
\hline 5 文節以上 & ( & & ) & $45(78 \%)$ & $13(22 \%)$ & $58(100 \%)$ \\
\hline すべて & $32(6 \%)$ & 66( & $13 \%)$ & $261(50 \%)$ & $159(31 \%)$ & $518(100 \%)$ \\
\hline
\end{tabular}

$(32+66) / 518)$ であった。 また，質問文の長さとシステム応答の関係 (表 11) を調べたところ， 対話カードは，主として短い質問文 (3文節以下) に対応していることがわかった。一般的には, 短い質問文ほど曖昧である。よって，図 12 のユーザ質問の hierarchyにおいて，上の方の曖昧 な質問文に対応するという対話カードの枠組みは，有効に機能していると考えられる.

また，ユーザ質問文の長さと知識ベースの検索結果の関係 (表 12) も調べたところ, 適切な テキストの割合は，質問文が長いほど少ないことがわかった。一般的には，長い質問文ほど専 門的なものが多い。よって，知識ベースはそのような質問文を十分カバーしていないと考えら れる。

一方，ユーザ質問文の長さとテキスト数 (ユーザに提示した選択肢の数) の関係については, 
表 12 ユーザ質問文の長さと知識ベース検索結果の関係

\begin{tabular}{|c|c|c|}
\hline 質問文の長さ & 平均テキスト数 & 適切なテキストの割合 \\
\hline 1 文節 $\quad(115$ 回 $)$ & 18.2 個 & $49 \%$ \\
\hline 2 文節 (46 回) & 9.1 個 & $28 \%$ \\
\hline ( 33 回) & 16.0 個 & $22 \%$ \\
\hline 4 文節 ( 22 回) & 10.5 個 & $10 \%$ \\
\hline 5 文節以上( 45 回) & 10.6 個 & $11 \%$ \\
\hline すべて $(261$ 回 $)$ & 14.4 個 & $35 \%$ \\
\hline
\end{tabular}

ユーザ質問文が 1 文節の場合のテキスト数が特に多かった。これは，B-3 の対話セッションの ようにユーザが入力した 1 キーワードを含むテキストを多数提示してしまうことが多かったの が原因である。一方，質問文がある程度長い場合は，選択肢の絞り込みのパラメータ (表 5)に よって，ユーザへの聞き返しとして適切な数に絞り込まれている.

\section{3 状況説明文抽出の評価}

2002 年 8 月 1 日 31 日の対話データベースから， 5 つ以上の選択肢が返されたユーザ質問 文をランダムに 100 個選んだ。さらに，選択肢中で上位 5 個中にランキングされているサポー 卜技術情報の状況説明文を, 評価者 1 名が「妥当」「不十分」「圥長」の 3 段階で評価した。上 位 5 個中において，タイトルが代表文として選ばれている 152 個のテキストは，代表文がその まま状況説明文となるため除外した。結果として，348(=100×5-152) 個の状況説明文が評 価の対象となった.

状況説明文の評価は，ユーザが選択肢を選ぶために必要十分な情報を，それぞれの選択肢が 含んでいるかどうかという観点から行った。 具体的には，まず質問文に対する選択肢 (5 個) ど うしを比較し, どの情報が選択肢を選ぶ上で最も重要かを判断する(この情報を, 最重要情報と よぶ).さらに，各々の選択肢について，以下のいずれかの評価を与える.

- 妥当: 最重要情報が過不足なく含まれている.

- 不十分: 最重要情報が含まれていない.

- 几長: 最重要情報以外の情報が著しく多く含まれている (目安としては, 最重要情報以外 の情報の文字数が, 最重要情報の文字数の $1 / 2$ を超えるとき).

表 13 に状況説明文の評価結果を示す．抽出された状況説明文のうち，61\%は妥当なもので あった。

また, 状況説明文の平均文字数は 68.9 文字, 状況説明文の抽出対象となった各テキストの代 表文の平均文字数は 81.6 文字であった. したがって, 提案手法による代表文の圧縮率 $(=(1$ - 状 況説明文の平均文字数/代表文の平均文字数) $\times 100)$ は $15.6 \%$ あった.

表 14 に状況説明文の評価の例を示す。この例においては, 評価者は,「音が出ない具体的な 
表 13 状況説明文抽出の評価結果

\begin{tabular}{c|rr}
\hline 評価 & \multicolumn{2}{|c}{ 選択肢数 } \\
\hline 妥当 & $213(61 \%)$ \\
不十分 & $27(8 \%)$ \\
几長 & $108(31 \%)$ \\
\hline 合計 & $348(100 \%)$ \\
\hline
\end{tabular}

表 14 状況説明文抽出の評価の例

\begin{tabular}{|c|c|c|}
\hline $\begin{array}{c}\text { 状況説明文 } \\
\end{array}$ & 元の文 & 評価 \\
\hline \multicolumn{3}{|l|}{$\begin{array}{l}\text { U: 音が出ない } \\
\mathrm{S}: \text { 以下の選択肢から選んでください. }\end{array}$} \\
\hline $\begin{array}{l}\text { 1. [NT] Crystal Audio や SoundBlaster } \\
\text { AWE32 利用時に音が出ない }\end{array}$ & (タイトル) & \\
\hline $\begin{array}{l}\text { 2. コントロールパネルの[サウンド] から } \\
\text { CHIMES WAVファイルをテストした場 } \\
\text { 合、ボリューム設定に関わらず }\end{array}$ & $\begin{array}{l}\text { コントロール パネル の[サウンド] から } \\
\text { CHIMES.WAV ファイルを テストした } \\
\text { 場合、ボリューム設定に関わらず、音は出 } \\
\text { ません。 }\end{array}$ & 妥当 \\
\hline $\begin{array}{l}\text { 3. 音楽の再生時に USB スピーカーからポッ } \\
\text { プ音が出る }\end{array}$ & (タイトル) & \\
\hline $\begin{array}{l}\text { 4. YAMAHA YSTMS55D USB スピーカ } \\
\text { セットのインストール後、スピーカのボ } \\
\text { リュームコントロールノブを使っても、非 } \\
\text { 常に音が小さい、または、音が出ない }\end{array}$ & $\begin{array}{l}\text { YAMAHA YSTMS55D USB スピーカ } \\
\text { セットのインストール後、スピーカのボ } \\
\text { リューム コントロールノブを使っても、 } \\
\text { 非常に音が小さい、または、音が出ない } \\
\text { ことがあります。 }\end{array}$ & 圥長 \\
\hline $\begin{array}{l}\text { 5. Windows サウンド }(. W A V) \text { ファイルを再 } \\
\text { 生時に }\end{array}$ & $\begin{array}{l}\text { Windows サウンド (.WAV) ファイルを再 } \\
\text { 生時に、音が出ない。 }\end{array}$ & 妥当 \\
\hline
\end{tabular}

環境 (サウンドデバイス名, アプリケーション名, ファイルの種類など)」が最重要情報である と判断した. 2 番, 5 番の選択肢は, 再生するファイルの種類を過不足なく述べているため,「妥 当」と判断した，一方，4番の選択肢は，サウンドデバイス名を含んでいるものの，それ以外の 発生条件や,「非常に音が小さい」といった情報を余分に含んでいるため,「圥長」と判断した.

提案手法による代表文の圧縮率が比較的小さかったのは,「穴長」な状況説明文が多いのが大 きな要因であった，具体的には，表 14 の 4 番の選択肢のように，ユーザが選択肢を指定する上 で重要な情報を含まないセグメントが，削除されずに状況説明文に含まれてしまったものが多 かった。より適切な選択肢を得るためには，選択肢の代表文どうしを比較して何が最も重要な 情報かを認識し，それを優先して選択肢に含める一方，それ以外の情報は除外することが必要 である。また，4番の選択肢では,「非常に音が小さい」と「音が出ない」を並列節として扱う ことによって，両者がともに聞き返しにとって圥長であることを認識して削除する必要がある.

「不十分」と評価された状況説明文については, 状況説明文抽出の対象となるテキストの代 表文 (3.5.2項) がテキストの内容をよく表していないものが多かった。これは，主にユーザ質問 文とテキストのマッチングに関する問題である.しかし，テキストの中には，ユーザ質問文と 
マッチする 1 文だけを抽出しても，良い代表文が得られないものもある．例えば，ユーザが遭 遇する問題 (「エラーが発生する」など) と，ユーザの具体的な状況 (エラーメッセージなど) が，それぞれ別々の文に書かれている場合は，提案手法はうまくいかない。このような場合は， 文脈解析などのより深い言語処理が必要となる。

\section{6 おわりに}

本論文では，大規模テキスト知識ベースを利用する対話的質問応答システムを提案した．シ ステムを実際に運用し, 得られた対話ログに基づいてシステムの評価を行い, 対話セッション の成功率 $76 \%$ ，妥当な状況説明文の割合 $61 \%$ という結果を得た。また，曖昧な質問への聞き返 しとして対話カードと状況説明文の抽出を組み合わせて用いる本システムの枠組みは，有効に 機能していることを示した。

今後の課題としては，対話カードの自動的な作成と，対話のコンテキストの利用があげられ る．対話カードの作成は，現在はすべて人手で行っているが，曖昧な質問を十分にカバーする 対話カード集合の構築にはコストがかかるので, 自動的に作成する手法が必要である．また， 対話のコンテキストの利用については，収集した対話ログをより詳細に分析することで，研究 を進める予定である。

\section{参考文献}

Ferret L., Grau B., Plantet M. H., Illouz G., Jacquemin C., and Masson N.Lecuyer, P. (2001). "QALC: the Question-Answering system of LIMSI-CNRS." In The Ninth Text REtrieval Conference (TREC-9), pp. 235-244. NIST Special Publication.

Fukumoto J., Kato T., and Masui F. (2002). "Question Answering Challenge (QAC-1) Question answering evaluation at NTCIR Workshop 3." In Working Notes of the Third NTCIR Workshop Meeting, Part IV: Question Answering Challenge (QAC1), pp. 1-10. National Institute of Informatics.

Hammond K., Burke R., Martin C., and Lytinen S. (1995). "FAQ Finder: A Case-Based Approach to Knowledge Navigation." In Proceedings of the 11th Conference on Artificial Intelligence for Apprications.

Harabagiu S., Moldovan D., Pasca M., Mihalcea R., Surdeanu M., Bunescu R., Gîrju R., Rus V., and Morărescu P. (2001). "The role of lexico-semantic feedback in open-domain textual question-answering." In Proceedings of the Association for Computational Linguistics. 
Hearst M. A. and Pedersen, J. O. (1996). "Reexamining the Cluster Hypothesis: Scatter/Gather on Retrieval Results." In Proceedings of ACM SIGIR.

Kawahara D., Kaji N., and Kurohashi S. (2002). "Question and Answering System based on Predicate-Argument Matching." In Working Notes of the Third NTCIR Workshop Meeting, Part IV: Question Answering Challenge (QAC1), pp. 21-24. National Institute of Informatics.

Kurohashi S. and Higasa W. (2000). "Dialogue Helpsystem based on Flexible Matching of User Query with Natural Language Knowledge Base." In Proceedings of 1st ACL SIGdial Workshop on Discourse and Dialogue, pp. 141-149 HongKong.

Kurohashi S. and Nagao M. (1994). "A syntactic analysis method of long Japanese sentences based on the detection of conjunctive structures." Computational Linguistics, 20 (4).

黒橋禎夫, 長尾真 (1999). 日本語形態素解析システム JUMAN version 3.61 使用説明書. 京都大 学大学院情報学研究科, http://www-lab25.kuee.kyoto-u.ac.jp/nl-resource/juman.html.

Lagus K. (2000). Text Mining with the WEBSOM. No. 110 in Acta Polytechnica Scandinavica, Mathematics and Computing Series. D.Sc.(Tech) Thesis, Helsinki University of Technology, Espoo, Finland.

Murata M., Utiyama M., and Isahara H. (2002). "A Question-Answering System Using Unit Estimation and Probabilistic Near-Terms IR." In Working Notes of the Third NTCIR Workshop Meeting, Part IV: Question Answering Challenge (QAC1), pp. 47-54. National Institute of Informatics.

西村英樹, 河野浩之, 長谷川利治 (1996). “WWW データ資源検索システムの実装と評価.”電 子情報通信学会技術研究報告 DE96-54, pp. 1-6.

NIST and DARPA (2001). The Ninth Text REtrieval Conference (TREC-9). NIST Special Publication.

Oddy R. N. (1977). "Information retrieval through man-machine dialogue." Journal of Documentation, 33 (1), pp. 1-14.

Rocchio J. (1971). "Relevance Feedback in Information Retrieval." In Salton, G. (Ed.), The SMART Retrieval System: Experiments in Automatic Document Processing, chap. 14, pp. 313-323. Prentice-Hall.

Takano A., Niwa Y., Nishioka S., Iwayama M., Hisamitsu T., Imaichi O., and Sakurai H. (2000). "Associate Information Access Using DualNAVI." In Proceedings of Kyoto International Conference on Digital Libraries 2000 (ICDL '00), pp. 285-289.

Wilensky R., Arens Y., and Chin D. (1984). "Talking to UNIX in English: An Overview of UC." Communications of the ACM, 27 (6), pp. 574-593. 
Zhai C., Tong X., Milic-Frayling N., and Evans D. A. (1996). "Evaluation of Syntactic Phrase Indexing - CLARIT NLP Track Report." In The Fifth Text REtrieval Conference (TREC-5), pp. 347-358. NIST Special Publication.

\section{略歴}

清田 陽司: 1998 年京都大学工学部電気工学第二学科卒業. 2000 年同大学院情 報学研究科修士課程修了. 2003 年同大学院情報学研究科博士後期課程単位認 定退学. 同年, 東京大学大学院情報理工学系研究科産学官連携研究員, 現在 に至る。質問応答システム, 情報検索, 自動要約の研究に従事.

黒橋 禎夫: 1989 年京都大学工学部電気工学第二学科卒業. 1994 年同大学院博 士課程修了. Pennsylvania 大学客員研究員, 京都大学工学部助手, 京都大学 大学院情報学研究科講師を経て, 2001 年東京大学大学院情報理工学系研究科 助教授, 現在に至る. 自然言語処理, 知識情報処理の研究に従事.

木戸 冬子: 1997 年マイクロソフト株式会社入社. 1998 年埼玉大学大学院理工 学研究科入学 (在学中). University Program 担当. 自然言語処理技術を用い たサポートシステムの効率化を目的としたストレリチアプロジェクトのリー ダーに従事. 2001 年科学技術振興事業団による理科教育用のデジタルコンテ ンツ開発にあたっては, 埼玉大学, お茶の水女子大学, 東京学芸大学との共 同開発プロジェクトのリーダーを担当した. 現在は, University Program 担 当として自然言語処理を中心とした大学との共同研究を担当している.

$(2002$ 年 11 月 22 日受付)

(2003 年 3 月 8 日 再受付)

(2003 年 4 月 10 日 採録) 